\title{
ТЕАТРАЛІЗАЦІЯ ПУБЛІЧНОЇ СМЕРТНОЇ КАРИ ЕПОХИ СЕРЕДНЬОВІЧЧЯ
}

У статті досліджується театралізаиія публічної смертної кари періоду Середньовіччя в Свроni. Автори аналізують суспільно-культурні функиії страт, систематизують основні типи публічних страт з огляду на їх сиенарно-режисерську і театрально-видовищну складову.

Ключові слова: публічна смертна кара, Середньовіччя, театралізоване дійство.

В статье исследуется театрализация публичных смертных казней эпохи Средневековья в Европе. Авторы анализируют общественно-культурные функиии казней, систематизируют основные типь публичных казней, учитывая их сиенарно-режиссерскую и театрально-зрелищную составляюшую.

Ключевые слова: публичная смертная казнь, Средневековье, театрализованное зрелище.

In this article the theatrical and spectacular aspects of public executions have been analyzed based on example of the medieval Europe. Authors enrich the knowledge of medieval studies, expand and systematize the knowledge of theatrical spectacle, defining the role and place of the public execution in the context of social and cultural processes, analyze the function of medieval public executions as theatrical events.

Keywords: public execution, medieval theatrical performance.

У різних країнах Свропи застосування смертної кари передбачалось як за тяжкі, так і за незначні вчинки: поряд з убивством каралися крадіжка більше 5 дукатів чи крадіжка на будь-яку суму, шахрайство (Німеччина), підготовка до вбивства, друкування книжок без надання на те дозволу, крадіжка зі зломом, дуель, недбале ведення корабельного журналу, носіння зброї поза службою, відмова від сплати податків, образа судді при виконанні службових обов'язків (Франція), вируб лісу, калічення тварин, злісне банкрутство, зневажання величності, обрізання монет, підпал будинку 3 метою крадіжки, крадіжка на суму понад 40 шилінгів (Англія), паління та продаж тютюну, вирубування заповідного дубу, бійка на спірних землях (Росія); у такий же спосіб суспільством засуджувалися гвалтівники, педерасти, повії, звідниці, винні у перелюбі, кровозмішенні, богохульстві, зневажанні святині, перериванні богослужіння, єресі, віровідступництві, святотатстві, чаклунстві, лжеприсязі. За таких умов кількість страчених досягала жахливих розмірів.

У цьому дослідженні загальнодоступні страти в середньовічній Європі розглядаються як соціально-культурне явище, яке має ознаки театралі- зованого дійства. У цьому полягає новий, раніше не досліджений науковий аспект проблеми.

Ставлячи за мету проаналізувати театрально-видовищну складову публічних страт на прикладі середньовічної Європи, автори ставили перед собою такі завдання:

- розширити й систематизувати знання про театралізовані видовища епохи Середньовіччя;

- визначити місце публічної смертної кари у контексті соціально-культурних процесів середньовічної Свропи;

- проаналізувати функції середньовічних загальнодоступних страт в Свропі як театралізованого дійства;

- простежити наявність режисерських засобів виразності в публічних каральних заходах середньовічної Європи;

- визначити основних дійових осіб публічних смертних кар в епоху Середньовіччя;

- систематизувати основні типи публічних страт Середньовіччя в Свропі з огляду на їх сценарно-режисерську і театрально-видовищну складову.

Хронологічні межі цього дослідження - середні віки - прийняте в історії позначення періоду світової історії між падінням Римської імперії 
(умовна дата 476 рік) і новою історією - Англійською буржуазною революцією XVII ст. (16401660 рр.). У цей період такі масові заходи, як публічні катування і страти, були типовим явищем соціокультурної реальності.

Смертна кара широко застосовувалась i поділялась на звичайну i витончено-жорстоку «кваліфіковану» (спалення, колесування, четвертування, підвішування за ребро, саджання на палю тощо) [1]. Найкривавішими були страти альбігойців, єретиків, іспанських маврів, євреїв, французьких та нідерландських протестантів. Масовість цього явища вражає: наприклад, «16 лютого 1568 року свята інквізиція 1 засудила на смерть усіх жителів Нідерландів, як єретиків; лише деякі особи, поіменно зазначені, були виключені 3 переліку засуджених» (переклад наш - М. Ю., K. Ю.-P.) [2, 175], і за цим вироком було покарано 25000 чоловік, у Німеччині за чародійство і чорну магію з 1625-го по 1630 роки було страчено 900 осіб; єпископ бамберзький протягом десяти років спалив 600 чол., вюрцбурзький - 900; у графстві Нейсі з 1640-го по 1651 загинуло на вогнищі близько 1000 осіб; в Англії за Генріха VIII стратили 72 000, за Єлизавети - понад 89 000; у Росії за Олексія Михайловича за підробку монет віддано на страту 7000 чол. [2, 176]. Загалом від слідчих дій інквізиції загинуло близько 5 млн чоловік [3].

Слід зазначити, що після хрещення Русі грецькі єпископи радили князеві Володимиру запровадити римсько-візантійську каральну систему, проте князь неприхильно поставився до цих побажань: «Не убивайте и не повелевайте убивать, даже если кто и будет повинен в чьей-то смерти» [цит. за 4, 17] (Владимир Мономах). Ще в 1069 році за часів «Русской правды» - першого письмового джерела з руського права - покарання смертю не передбачалося. Проте смертна кара на Русі використовувалась як у випадках, передбачених законом, так і в позазаконних.

Однак до смертної кари вдавалися багато правителів Русі XIII-XIV століть. Законодавчо смертна кара на Русі запроваджується лише в 1398 році у Двірській уставній грамоті. Особливе поширення смертна кара отримує за правління Івана Грозного, коли була страчено близько 4000 чол.

У Середньовіччі не існувало таких соціально-культурних інституцій, як преса, кіно, телебачення, радіомовлення тощо. Функції засобів масової інформації виконували різні публічні заходи, в тому числі й публічні страти та катування. При цьому вони виконували соціальноідеологічні й художні завдання, завжди органічно поєднуючи реальне життя і мистецтво театралізованого масового дійства. Публічні театралізовані дійства, до яких належать і публічні страти, виконували в середньовічному суспільстві важливі соціально-культурі функції: ідеологічно-виховну, інформаційно-комунікативну, компенсаторну, регуляторну, стабілізаційну, естетичну та ін. Невід'ємною складовою публічних театралізованих заходів $€$ їх колективний характер, адже проводились вони завжди при великій кількості глядачів й іноді за їх активної участі.

Виховній ролі середньовічних страт і катувань належить провідне місце серед інших функцій. Адже емоційно-психологічний та ідеологічний вплив на глядачів притаманних їм засобів виразності надто сильний і підпорядкований певній суспільній ідеї. На повчальний ефект від страшного видовища звертає увагу Йоганн Хейзінга: «Жорстоке збудження і груба участь, викликані видовищем ешафоту, були важливою складовою духовного життя народу. Це вистави 3 повчанням. Для страшних злочинів винаходяться страшні покарання» (переклад наш - М. Ю., К. Ю.-Р.) [5, 15]. Інформаційно-комунікативна роль безперечно теж вагома, оскільки такі публічно-масові заходи $€$ формою людського спілкування і мають на меті обмін вербальною та невербальною інформацією. Яскраво простежується і компенсаторна функція прилюдних страт доби Середньовіччя — натуралізм таких видовищ викликав емоційний стрес у глядачів, що і слугувало своєрідною формою активного відпочинку і «адреналінової» розваги, що в свою чергу було різновидом дозвілля та засобом відновлення духовних і фізичних сил після буднів. Шляхом організації публічних смертних покарань формувалися, врегульовувалися і підтримувалися взаємовідносини між різними суспільно-майновими прошарками, між жінками і чоловіками, старшими і молодшими, між віруючими і єретиками і т.д. Безумовно, публічність смертної кари привносила стабілізацію в суспільство, забезпечуючи його керований розвиток, який спрямовувався церковною та світською владою. У публічних смертних стратах знаходилось місце й естетичному чинникові - художньо оформлювався публічний простір, створювалися сценарій, відповідні музика, костюми, атрибутика.

Невід'ємною складовою публічних театралізованих заходів $\epsilon$ їх колективний характер, адже проводились вони завжди при великій кількості глядачів й іноді за їх активної участі (наприклад, каменування). Саме колективний характер смертної кари відрізняє іï від убивства — вона вико- 
нується не за волею однієї особи, а за рішенням загальнодержавної влади, тобто на основі вироку, винесеного представниками влади або спеціальним повноважним органом. Тобто в самій суті поняття смертної кари вже закладено колективну складову.

Перші фахові розробки питання смертної кари італійського просвітителя маркіза Чезаре Беккаріа Бонесано (1738-1794) - просвітителя, філософа і теоретика кримінального права, зроблені в трактаті «Про злочини і покарання» (1764 рік), а саме у параграфі 28 «Про смертну кару», і містять в собі роздуми про ії обов'язкову колективну складову. Беккаріа зазначає, що смертна кара «є війна нації з громадянином, внаслідок чого нація вважає необхідним чи корисним знищити громадянина» (переклад наш - M. Ю., К. Ю.-Р.) $[6,85]$.

Підтвердженням тези про приналежність середньовічних публічних страт до категорії публічних театралізованих дійств $\epsilon$ також факт наявності у структурі публічних страт трьох складових, характерних для всіх театралізованих заходів. Це певний сценарій, як літературна основа дійства, виконавці як суб'єкти сценічного мистецтва i глядачі, які в процесі публічної страти фактично перетворюються із пасивних спостерігачів на глядачів і учасників, без яких це специфічне дійство не виконує свої суспільні функції.

Про театрально-видовищну складову публічних покарань і про різний вплив таких дійств на глядачів писав уже у XVIII ст. згаданий вище Беккаріа: «Смертна кара для більшості людей є виставою, для меншості - предметом співчуття, змішаного з обуренням; обидва ці почуття займають розум глядачів більш, ніж рятівний страх, котрий закони мають на увазі викликати. Навпаки, у покараннях м'яких і пролонгованих цей рятівний страх $€$ панівним відчуттям, оскільки іншим почуттям тут місця немає». I далі Беккаріа підсумовує — якраз вплив на глядача $€$ головною метою страти, а не саме́ покарання: «Межа, яку законодавець не має переступати у суворості покарання, здається, пролягає там, де почуття жалю починає брати гору над усіма іншими в свідомості глядачів покарання, яке виконується більш для цих останніх, ніж для злочинця» (переклад наш - М. Ю., К. Ю.-Р.) [6, 87].

Користуючись театральною термінологією, до неодмінних дійових осіб середньовічної смертної кари як театралізованого дійства можна віднести ката і злочинця. «У наш час смертні вироки виконує спеціально призначена для цього особа. У давнину ці обов'язки брали на себе первосвященики (понтифекс максимус у Римі), царі азійських монархій, римські консули і трибуни, а в євреїв царські отроки, військові сановники, обвинувачі та свідки, родичі загиблого, іноді просто народ. Так само й в середньовічній Європі смертний вирок виконувало саме суспільство в особі своїх представників, а іноді один із суддів чи родич убитого або убивці. Так, наприклад, Іван Грозний, виносячи вирок за політичними справами, неодноразово доручав його виконання своїм наближеним (князь М. Черкаський, Малюта Скуратов, князь М. Темрюкович). За Петра I князь-«кесар» Ф. Ромодановський, князь В. Голіцин, О. Меншиков не гребували рубати голови бунтарям-стрільцям, та i сам цар власноруч стратив у Преображенському п'ятьох стрільців. Ще довго після Петра в Росії зберігався звичай запрошувати або брати силоміць на допомогу катові кого-небудь 3 публіки, поки врешті-решт у 1768 році було наказано призначати для виконання страти тяжких злочинців» (переклад наш - М. Ю., К. Ю.-Р.) [1]. У період татаро-монгольської навали хани видавали руському православному духовенству ярлики, згідно 3 якими священнослужителі мали право карати смертю. Ярлик, виданий татарським ханом Менгу Теміром, онуком Батия, надавав право київському митрополитові Кирилу страчувати за огуду православної церкви, як і за будь-яке порушення наданих духовенству привілеїв. У 1227 році, як свідчить літопис, у Новгороді за чаклунство «изъжогша волхвов четыре».

Як і в давнину, так і в середні віки традиційним місцем виконання смертної кари, яка здійснювалася принародно, був центр міста - лобне місце. Самій процедурі страти передувала низка подій, що їх можна трактувати як певний сценарій: для залучення найширшого кола глядачів розсилалися глашатаї і сурмачі або ж дзвонили в дзвони.

Популярності стратам серед глядачів додавали й самі особи злочинців. Тут в епоху Сeредньовіччя панувала певна дискримінація. Як зазначає професор кримінального права та процесу Київського університету О. Ф. Кістяковський (1833-1885) у своїй магістерській праці «Дослідження смертної кари» (1867), «в середні віки по всій Західній Європі два панівних класи, духовенство і дворянство, користувалися привілеєм вилучання від смертної кари та інших страждальницьких страт: духовенство становило майже всуціль виняток, дворянство - в менших розмірах, вилучанням у багатьох випадках і за багато вчинків, за які особи інших класів підлягали смертній карі» (переклад наш - М. Ю., К. Ю.-Р.) [2, 140]. Поступово, з розвитком юриспруденції в Англії, 
привілей вилучання за тяжкі злочини від смертної кари «поширився на світських людей за наступною юридичною функцією: вміння читати було ознакою приналежності до духовного прошарку (першочергово лише він один умів читати)» (переклад наш - М. Ю., К. Ю.-Р.) [2, 147]. Звісно, що страта відомих людей привертала більше уваги глядачів. «Нерідко засудженими були вельможі, і тоді народ отримував ще більше задоволення від виконання невблаганного правосуддя» (переклад наш - M. Ю., К. Ю.-P) [5, 15].

Театралізація середньовічної страти полягала також у створенні певних декорацій і костюмування. Зрозуміло, що для огляду публіці обов'язково виставлялися самі знаряддя страти, але при цьому «влада намагалася нічого не пропустити для досягнення найбільшого враження від цього видовища: знаки гідності супроводжували засуджених під час скорботної процесії. Жан де Монтегю, королівський мажордом, предмет ненависті Іоанна Безстрашного, возсідає високо на повозці, котра повільно рухається за двома сурмачами. Він вдягнений в ошатне вбрання - відповідно до його стану: каптур, що спадає до пліч, упланд², наполовину червоні, наполовину білі панталони і черевики iз золотими шпорами: на цих шпорах його обезголовлене тіло і залишиться потім висіти на шибениці» (переклад наш - М. Ю., К. Ю.-Р.) [5, 15-16]. Інакший вигляд має зовнішнє оформлення страти: «багатого каноніка Нікола д’Оржемона - жертву помсти арманьяків - у 1416 році провозять через Париж на возі для сміття»; дещо модифікується і сценарій самого покарання — «він бачить як обезголовлюють двох його товаришів, перш ніж самому йому виносять вирок - довічне ув'язнення» (переклад наш - М. Ю., К. Ю.-Р.) [5, 15-16].

Багато описів спалення єретиків знаходимо в художній літературі, в образотворчому мистецтві. Так привертає увагу опис Вольтером головних уборів двох своїх героїв - Панглоса і Кандіда: «Через тиждень вони були одягнені в санбеніто ${ }^{3} \mathrm{i}$ увінчані паперовими митрами. Митра і санбеніто Кандіда були розписані перевернутими вогняними язиками і дияволами, в яких не було ні хвостів, ні кігтів. Дияволи ж Панглоса були з хвостами і 3 кігтями, і вогняні язики горіли прямо» (переклад наш - М. Ю., К. Ю.-P.) $[7,111]$

Всі види смертної кари перелічити неможливо: людська фантазія з особливою витонченістю завжди винаходила способи комбінування різних страт і тортур перед ними. У Росії Соборне уложення ${ }^{4} 1649$ року санкціонувало три види «кваліфікованої», тобто обтяженої страти: спа- лення, заливання горла розплавленим залізом і закопування живцем у землю. Проте популярними також були колесування, четвертування, саджання на палю, шмагання до смерті батогами і шпіцрутенами (фактично скасовано лише законами від 17 квітня 1863, 8 травня і 28 жовтня 1871 років), повішання (для більшої ганьби приречених вішали поруч 3 двома собаками чи вовками, а перед стратою водили по вулицях в блазнівському одязі чи верхи на віслюкові, піддавали паплюженню 3 боку ката, виставляли біля ганебного стовпа 3 накладанням залізного ошийника).

Безперечно, найбільш визначною стратою в історії людства стало розп'яття Ісуса Христа. Римляни не були винахідниками цього виду страти, ймовірно, це винахід фінікійців. Засудженого до розп'яття кати роздягали, залишаючи лише пов'язку на стегнах, прив'язували до дерев'яного хреста і шмагали шкіряними батогами чи щойно зрізаними прутами. Потім приречений мав нести свій хрест до місця страти. Зазвичай це був пагорб поза містом чи просто узбіччя дороги. Хрест вкопували в землю, мотузками піднімали засудженого на перекладину, прив'язували до неї, а потім прибивали цвяхами руки. Ноги іноді лише прив'язували, а іноді також цвяхували.

Муки розп'ятих тривали довго, а потім (зазвичай ближче до вечора) їм перебивали гомілки, що призводило до швидкої смерті від задухи. Дихати на хресті можливо лише тоді, якщо дещо піднімати грудину, спираючись на ноги. Таким чином це прискорювало смерть засуджених і позбавляло необхідності стерегти їх, очікуючи їхню природну смерть від зневоднення чи теплового удару. В Свангелії від Іоанна про страту Ісуса Христа сказано: «Отож вояки прийшли і переламали першому голінки і другому, який був з Ним розіп'ятий. Та коли підступили до Ісуса й побачили, що Він уже мертвий, то голінок не перебивали Йому, лиш один 3 вояків списом Йому бік проколов. I потекла негайно ж кров - і вода» [8, 19:32-34].

Популярне в греків і римлян своєю тривалістю і стражденністю розп'яття або повішання на хресті було відкинуте всіма християнськими народами через благочестиве нагадування про хресну смерть Христа Спасителя. Проте інколи і в середні віки трапляються прояви такого покарання так Людовик Товстий у 1127 році наказав розіп'яти злочинця, а поруч із ним прив'язати собаку i бити iї, аби вона злилася і кусала покараного.

Існував також спосіб розп'яття вниз головою. Він застосовувався іноді в євреїв і в єретиків у Франції. Хрести були двох видів - косий (пе- 
рехрещені дві жердини рівної довжини, кінці яких укопані в землю) і прямий (традиційний хрест). Проте суть в них одна - зробити людину нерухомою й приректи на повільну смерть.

Маючи за мету проаналізувати видовищну складову публічних смертних покарань, варто дослідити й систематизувати найбільш широко застосовані види смертної кари періоду Середньовіччя: розп'яття, спалення, повішення, утоплення, зварювання живцем, четвертування, колесування, обезголовлення, здирання шкіри, поховання живцем, саджання на палю, аркебузування (розстріл), підвішування на гак за ребро, щипці, заливання горла розплавленим металом, каменування, ганебний стовп, диба, ублієти, шмагання батогами, палицями тощо.

Поза увагою у дослідженні були залишені такі покарання та тортури, як таврування, осліплення, карнаушані $\epsilon^{5}$, відтинання кисті рук, ампутація ніг, виривання зубів, «крісло єретика», «вилка єретика», тортури вогнем, водою, батогом, «іспанський чобіт», розтягування тіла, — як ті, що не проводилися при значній кількості глядачів і тому не можуть бути трактовані як різновид масових дійств або як такі, що не призводили до смерті засудженого, а лише калічили.

Спалення активно застосовувалось у багатьох країнах світу і в дохристиянський період — римська влада карала багатьох ранніх християнських мучеників, саме спалюючи їх. Проте розквіт цього способу настав у середні віки і застосовувався за релігійні злочини. «В 1022 р. в Орлеані запалали перші вогнища 3 єретиками» (переклад наш М. Ю., К. Ю.-Р.) [9, 87]. Витоки цього покарання слід шукати у візантійському праві. За часів Biзантійської імперії спалення було передбачено для наполегливих послідовників Заратустри за їхнє поклоніння вогню. В 1184 році Синод Верони видав наказ про те, що спалення на вогнищі визнається офіційною карою за єресь. До XVII ст. цей наказ імплементували багато країн Європи. Найзнаменитішим спаленням на Русі стала страта протопопа Авакума, сподвижника розкольництва. Страта на вогнищі в Росії була більш страждницькою, ніж в Європі, оскільки являла собою скоріше не спалення, а копчення живцем на слабкому вогні $[2,251]$.

«За підрахунками, наведеними Вольтером, у Європі спалено понад 100 тисяч чоловік за чаклунство. Інші стверджують, що в самій лише Німеччині страчено не менше цієї кількості» (переклад наш - М. Ю., К. Ю.-Р.) [2, 177]. Найвідоміші особистості страчені таким чином: Жак де Моле (магістр Ордену Тамплієрів) 1314 р.; Ян Гус, 1415 р.;
Жанна д’Арк - у лютому 1431 засуджена духовним судом в Руані як єретичка і відьма, 30 травня спалена на вогнищі 6 [10]. Найбільшою кровожерністю відзначалася «іспанська інквізиція, за вироками якої було спалено живими 34 тис. 658 чол. і 18 тис. 49 чол. у вигляді зображень» (переклад наш М. Ю., К. Ю.-P.] [2, 142]. Також тут варто зазначити, «що менш за все гонінню на відьом сприяли в Італії» (переклад наш - М. Ю., К. Ю.-Р.) $[11,310]$.

Тут слід зупинитися на особливому виді спалення - спалення у вигляді зображень. Ідеться про своєрідне виконання заочного вироку. Суть такого покарання полягала в спаленні не самого злочинця, особиста присутність якого при цьому 3 певних причин була неможлива, а його опудала або зображення. За таких обставин смертна кара шляхом спалення набуває особливо виразних рис театралізованого публічного заходу. Адже комунікативна його функція тут набуває особливого значення поруч з виховною складовою. Публічність винесення і виконання вироку надавала «страті» найширшого інформаційного розповсюдження серед мешканців міста та околиць, досягаючи при цьому не меншого пропагандистського та повчально-виховного результату.

Йдучи за настановами Старого Заповіту: «А чоловік або жінка, коли будуть вони викликати духа мерців або ворожити, будуть конче забиті, камінням закидають їх, кров їхня на них!» [12, 20:27], «Чарівниці не зоставиш при житті» [13, 22:17], посилилось переслідування відьом інквізицією. Протягом століть це закінчилося спаленням мільйонів жінок на вогнищах на території Німеччини, Австрії, Швейцарії, Англії, Шотландіï, Іспанії. Особливе переслідування саме жінок інквізицією пояснюється, що «в середні віки побутувало загальне переконання, що люди, особливо жінки, можуть вступати в безпосередній зв'язок 3 дияволом на згубу своїм ближнім. Закони того часу передбачали спалювання всіх тих, хто викликає злих духів» [2, 175].

«Люди жили в атмосфері чуда, що вважалося повсякденною реальністю» (переклад наш - $M$. Ю., К. Ю.-Р.) [14, 191], і тому спалення відьом було таким популярним публічним видовищем, яке мало на меті насамперед запобігти відьомству та залякати присутніх глядачів. Здалеку стікався народ до місця страти. Іноді публічна церемонія спалення на вогнищі - аутодафе — мала особливо масовий характер, при цьому єретики спалювалися десятками. Святково одягнені, збиралися представники місцевої влади: єпископ, каноніки і священики, бургомістр і члени ратуші, судді, суд- 
дівські засідателі. У супроводі ката на возах привозили зв'язаних відьом і чарівників. Зазвичай приречених одягали в сірий одяг. Поїздка до місця страти була важким випробуванням, адже народ не пропускав моменту зло посміятися і познущатися над засудженими відьмами, які йшли в останню путь. Коли нещасні нарешті діставалися до місця страти, кати приковували їх ланцюгами до стовпів і обкладали сухим хмизом, дровами і соломою. Після цього розпочинався урочистий ритуал, під час якого проповідник ще раз застерігав народ від підступності Диявола і його поплічників. Потім кат підносив факел до вогнища. Зазвичай улаштовували чотирикутне вогнище, для якого привозили цілі вози дров. Досить часто приреченим у горло вставляли залізний кляп. Він не давав змоги крикам жертви заглушати духовну музику, якою супроводжувалося спалення. Відомо, що Джордано Бруно був спалений у Римі в 1600 році саме із залізним кляпом у роті. Проте частіше кат позбавляв людину від страждань горіти живцем упорядники страти доглядали за вогнищем за допомогою багра для перемішування, i, як тільки займалося багаття, встромляли його в серце жертви, отож людина миттєво помирала.

Безпосередньо спаленню мали передувати причастя і сповідь. Але жага помсти призводила іноді до несумісних з християнством речей. В Англії і Франції могли «відмовити приреченому до страти не лише в причасті, а й у сповіді. Тим самим його прагнули позбавити спасіння душі, обтяжуючи страх смерті неминучістю пекельних мук. <..> Королівський едикт від 12 лютого 1397 р. звелів допускати до сповіді засуджених до смерті злочинців. П'єр де Краон, чиїми зусиллями було прийнято це рішення, спорудив у Парижі поруч із шибеницею кам'яний хрест, стоячи біля якого, брати мінорити могли надавати духовну підтримку злочинцям, котрі каялися» (переклад наш - M. Ю., К. Ю.-Р.) [5, 32].

Після того як офіційні особи розходилися по домівках, кати продовжували підтримувати вогонь доти, доки не залишався самий попіл. Кат ретельно збирав його, а потім розвіював під ешафотом чи в якомусь іншому місці, щоб ніщо більше не нагадувало про богохульні справи страчених спільників диявола.

Поступово масовість явища публічного спалення занепадає. «Наприкінці XV століття в рік було спалено по 2 тисячі єретиків, 3 1746го по 1757-й спалено було лише 10, з 1758-го по 1774 pp. — лише 2, з 1774-го по 1783 pp. — теж 2» (переклад наш - М. Ю., К. Ю.-Р.) [2, 190].
Вішання приречених використовувалося скрізь упродовж історії людства. Відомо, що ця страта вперше була винайдена і застосована в Персидській імперії. Такому покаранню зазвичай передувало формулювання: «Засуджений вішається за шию до смерті». Ранній метод вішання був такий — кат накидав зашморг на шию полоненому чи злочинцеві, інший кінець перекидав через дерево, і тягнув, поки жертва не задихалась. Іноді використовувалися віз або драбина, яку кат вибивав 3-під ніг жертви.

Смертна кара шляхом вішання вважалась особливо принизливою, ганебною смертю і застосовувалася до військових, які переходили на бік ворога. Така смертна кара була дуже поширена під час військових дій — вішали полонених солдат, дезертирів, а також цивільних. Вішали й при придушенні заколотів, повстань і селянських заворушень.

Вішання було як одним з видів смертної кари, так і одним з видів тортур. Засуджений міг бути просто страчений, повішений у зашморгу зі зламаною шиєю. Однак, якщо його катували, то застосовувалося багато методів. Зазвичай людину «розтягували і четвертували» перед тим як вішати. Для надзвичайно важких злочинів (таких як злочинні наміри проти короля), просто вішання було недостатньо. Засуджених різали на шматки живцем, перш ніж повісити [2, 248].

Вішання як вид публічної страти тривало досить довго. Так, за організацію змови, яка призвела до повстання 14 грудня 1825 року, були повішені декабристи Пестель, Бестужев-Рюмін, Рилєєв, Сергій Муравйов-Апостол, Каховський [15].

Утоплення застосовувалось в тому разі, коли екзекуція проводилась у широких масштабах, а також до тих, хто ганебно лаявся. За таку провину дворяни могли обійтися штрафом, а простолюдини підлягали утопленню. Цих нещасних клали в мішок (іноді з яким-небудь повчальним написом), зав'язували шнурівкою і кидали у воду [2, 252].

У хроніках описано три сценарії покарання через зварювання живием. Всі три являли собою болючий і повільний спосіб страти, який був не надто поширений так, як інші види покарання, проте використовувався як в Свропі, так і в Азії впродовж 2000 років. Перший сценарій передбачав кидання приреченого в казан з киплячою водою, смолою або олією. Поблажливості не було навіть до жінок. На Русі, особливо за царя Івана Грозного, широко застосовувалось кип'ятіння в олії, вині чи воді. Іван Грозний карав таким чином державних злочинців $[2,249]$. Такий спосіб був максимально милосердним - людина прак- 
тично миттєво втрачала свідомість від больового шоку, що спричинявся опіком всієї поверхні тіла. О.Ф. Кістяковський зазначає «Іван Грозний в один день стратив, як державних злочинців, 300 чоловік у Москві; за переказами літописців, у Новгороді протягом п'яти і більше тижнів він щодня піддавав смертному покаранню через утоплення за мінімальну зраду від 500 до 1 тис. 500 чоловік, а всього, якщо вірити літописцеві, стратив близько 60 тисяч людей» (переклад наш - $M$. Ю., К. Ю.-P.) [2, 172].

Під час застосування другого сценарію, попередньо зв'язаного засудженого занурювали в казан 3 холодною водою. Кат розпалював вогонь під казаном, щоб вода поволі закипала. Отож засуджений залишався при свідомості і страждав до півтори години.

Однак існував i третій, найстрашніший варіант цієї страти - підвішену над казаном 3 окропом жертву повільно опускали до казана, так щоб тіло варилося поступово, протягом декількох годин. При цьому до ніг засудженого прив'язували вантаж, аби він не міг висмикувати кінцівки 3 окропу, і процес ішов безперервно. Це не було катуванням, наприклад, в Англії це було цілком законним покаранням за підробку асигнацій чи за часів Генріха VIII (близько 1531 року) передбачалося для тих, хто зважився на отруєння. Максимально тривалий строк такої страти існував за часів правління Чингісхана, коли засуджений залишався живим і терпів пекельні муки протягом цілої доби. При цьому його періодично піднімали 3 окропу й обливали крижаною водою.

Четвертування - різновид смертної кари, що обов'язково включав відсікання кінцівок. Як стає зрозумілим із самої назви, тіло засудженого розділяють на чотири (або більше) частини. Для більшого залучення глядачів до дійства і пролонгації його в часі, після здійснення покарання частини тіла окремо виставлялись на публічний огляд, іноді розносились по чотирьох заставах чи воротам середньовічного міста. У різних країнах існували різні сценарії виконання четвертування.

В Англії традиційним покаранням для жінок за зраду було спалення, а для чоловіків - четвертування. Зрада передбачала два іiі різновиди: проти верховної влади - короля та проти законного господаря (включаючи вбивство чоловіка дружиною). В Англії та потім у Великобританії (аж до 1829 року, формально відмінено лише в 1867 році) четвертування було складовою частиною найбільш страждницької смертної кари «повішання, потрошіння і четвертування», — яку призначали за особливо тяжкі державні злочини, такі як зрада чи замах на життя короля. Так страчували лише чоловіків. Жінок спалювали на багатті.

Приреченого на четвертування везли вулицями міста до місця страти розтягнутим на дерев' яній рамі. Потім придушували, але не до смерті, вішаючи на короткий час на шибеницю. Потім знімали 3 мотузки і випускали йому нутрощі, розпорюючи живіт. Тільки після цього його тіло розтинали на чотири частини, відрубали дітородні органи, а потім голову. Останнє, що могла бачити жертва, — власне серце. Нутрощі спалювали. За передсмертне каяття і як на знак королівської милості сценарій міг модифікуватися - злочинця могли четвертувати, відтинаючи спочатку голову, а потім кінцівки. Як правило, п'ять частин тіла (кінцівки i голову) виставляли на привселюдний огляд у різних районах міста або «там, де король вважатиме за потрібне» як попередження [2, 212, 250, 252].

У Франції четвертування виконували за допомогою коней. Засудженого прив'язували за руки i за ноги до чотирьох сильних коней, яких підганяли кати. Коні бігли врізнобіч і відривали кінцівки. Фактично для виконання процедури такого четвертування доводилося підрізати засудженому сухожилля, щоб прискорити страту. Потім тулуб засудженого кидали у вогонь. Розриванню, як правило, передувало катування: злочинцеві щипцями відривали шматки м'яса зі стегон, грудей, литок $[2,213]$.

У Росії практикувався, мабуть, найменш мученицький спосіб четвертування: засудженому відрубали сокирою ноги, руки й потім голову. Він застосовувався за образу царя, за замах на його життя, іноді за зраду, а також за самозванство. Так було страчено Степана Разіна (1671), Омеляна Пугачова (1775) - йому спочатку відтяли голову, а потім уже кінцівки. Це було останнє четвертування в Росії. В Свропі четвертування виходить з ужитку наприкінці XVIII - на початку XIX століття.

Колесування - зламування на колесі - було одним з видів тортур, а пізніше й покарання. Сценарій розгортався так: до ешафоту прив'язували в горизонтальному положенні хрест на кшталт хреста Святого Андрія, зроблений з двох колод. На кожній $з$ гілок хреста робили дві виїмки на відстані в один фут одна від одної. Жертву роздягали, розтягували на хресті за руки і ноги, розкладаючи й прив'язуючи їх до дощок хреста так, щоб злочинець лежав горілиць. Кожна кінцівка лежала на одній з гілок хреста, і в кожному місці зчленування прив'язувалася до хреста. Потім кат бив великим молотком або залізним чотирикутним ломом чи 
окованим залізом колесом по зап'ястках, щиколотках, ліктях, колінах і стегнах, ламаючи кістки, які лежали саме над виїмкою. Таким чином переламували кістки кожного члена в двох місцях. Цей процес повторювався декілька разів, при цьому кат намагався не завдавати смертельних ударів. Екзекуція закінчувалась двома чи трьома ударами в живіт і ламанням станового хребта. Перед глядачами поставало криваве видовище - жива купа з людської плоті. Щоправда, часто судді наказували умертвити засудженого перед тим як переламати йому кістки.

Переламаного таким чином злочинця клали на горизонтально поставлене колесо так, щоб п’ятки торкалися потилиці, прив'язували до колеса, пропускаючи мотузку крізь зламані суглоби і залишали його в такому положенні помирати. Колесо нагадувало звичайне колесо від воза, тільки більшого розміру і з більшою кількістю спиць. Іноді замість колеса використовували масивні залізні прути 3 набалдашником, котрий разом 3 жертвою піднімали на жердині, щоб птахи могли клювати ще живу жертву. Це було дуже жорстоке покарання, яке ще обтяжувалося посоромленням злочинця.

Після повішання, колесування стало найпоширенішим (водночас і найжорстокішим) видом страти в Свропі від раннього середньовіччя і до початку XVIII ст. Колесування отримало на Русі широке запровадження за часів Петра I. Разом із спаленням на вогнищі і четвертуванням це була найпопулярніша за своєю театральністю смертна кара, що їі виконували на всіх площах Європи. Сотні шляхетних людей і простолюдинів із цікавістю приходили подивитися на колесування, особливо якщо страчували жінок [2, 249].

Обезголовлення - це відтинання голови живій жертві. Зазвичай для ката засобом страти був великий ніж, меч або сокира. Обезголовлення вважалося «достойним» видом страти для дворян і людей шляхетного походження, які були воїнами і мали померти від меча. «Недостойна» смерть була б на шибениці чи на вогнищі. Якщо кат добре нагостреною сокирою чи мечем поціляв жертву влучно і з одного удару, то обезголовлення було безболісним і швидким. Якщо засіб страти був тупим або виконавець недолугим, то багатократні удари завдавали великого болю $[2,248]$. Здебільшого приречений давав монету катові, щоб той зробив усе швидко. Коли голову було відтято, то кат піднімав іiі і демонстрував натовпу. «Легкодумство середньовічних людей загальновідоме» $[14,191]$ і тому побутувала думка, що відтята голова протягом приблизно десяти секунд ще жива, $\mathrm{i}$, таким чином, голову людини піднімали, щоб вона «оглянула» натовп. Традиційним також було формальне вибачення ката перед жертвою. Відомо, що «Месір Мажар дю Буа, арманьяк, якого мали обезголовити в 1411 р. у Парижі в дні бургиньонського терору, не лише дарує від щирого серця вибачення катові, про яке той просить відповідно до звичаю, а й бажає, щоб кат обмінявся 3 ним поцілунком» $[5,15]$

Здирання шкіри - це один 3 методів страти чи тортур, залежно від того, скільки шкіри знято. Шкіру здирали як 3 живих, так і 3 мертвих людей - 3 ворогів-небіжчиків чи злочинців, аби викликати жах у глядачів. Цей спосіб має дуже давню історію. Ще ассирійці знімали шкіру $з$ полонених ворогів і заколотників-правителів і прибивали їі до стін їхніх міст як попередження тим, хто захоче оскаржити сильнішу владу. У Західній Європі використовувався як метод покарання зрадників і перебіжчиків [2, 252].

Поховання живием - одне зі стародавніх покарань, яке досить широко застосовувалося і в Середньовіччі. Закопування, «окопание», живцем у землю призначалось, як правило, дружинам за вбивство чоловіка, дітей або просто за крадіжку [2, 251].

Саджання на палю - надзвичайно жорстока кара, що прийшла до Європи зі Сходу і набула в епоху Середньовіччя широкого застосування. Суть їі полягала в тому, що людину саджали на обструганий кілок, вкопаний у землю, направляючи вістря в анальний отвір, попередньо змащений жиром. Часто на малюнках зображають, як шпичак виходить 3 горла засудженого, однак на практиці це був рідкісний випадок. Залежно від кута, під яким встромлявся кіл, він на практиці міг вийти 3 живота чи, що траплялося частіше, 3 пахви.

Застосовували декілька різновидів паль: гладкі і нестругані зі скалками, гострі й тупі, широко варіювалася товщина кілка і його розширення до нижнього кінця. Рафінованою формою палі для покарання була так званий персидська паля. Він відрізнялася тим, що мала «сидіння» на зразок стільця, для того щоб людина не могла відразу під власною вагою опуститися на палю і померти. Поступово висота «стільця» зменшувалась, паля входила дедалі глибше, додаючи нових страждань. Така смертна кара могла тривати годинами і виконувалась привселюдно. Площа наповнювалась криками мученика, які, звісно, вселяли страх перед владою в простих містян [2, 252-253].

Петро I запровадив до переліку офіційних старт аркебузування, тобто розстріл. Сама назва «розстріл» походить від гнотової рушниці поши- 
реної в XV - XVI ст. у Західній Європі, яку заряджали 3 дула. Розстріл не вважався ганебним покаранням і не безчестив ім'я розстріляного [2, 253]. Розстріл набув особливого поширення в більш пізні часи.

До наявних раніше видів страт згодом додалося підвішування за ребро: смертник мав висіти боком, зі звішеними донизу головою, руками й ногами. Загалом підвішування застосовувалося дуже широко, підвішували за ребро, ноги й волосся та інші частини тіла. Після тривалого висіння в людини, підвішеної за ноги, відбувався крововилив у мозок, що спричиняло смерть. Щоб збільшити страждання покараного, застосовувалися різні види гир.

Хоча щиипиі, мабуть, можна віднести радше до виду тортур, але від цих тортур часто помирали. Суть знущання полягала в тому щоб щипцями відірвати шматок м'яса. Зазвичай така процедура комбінувалася 3 вливанням розплавленого свинцю в горло, а також на рани. Заливання горла розплавленим свинцем застосовувалося виключно до фальшивомонетників. У 1672 році цей різновид смертної кари у Росії замінили на відтинання обох ніг і лівої руки злочинця [2, 253].

Безперечно, безпосередньої найактивнішої участі глядачів вимагало покарання шляхом кaменування, або лапідаџіï. Коли засудженого вели містом, то з ним ішов судовий пристав зі списом у руці, на якому майорів прапор, щоб привернути увагу тих, хто може виступити на його користь. Якщо така людина не знаходилася, то засудженого забивали камінням. Каменування виконувалося двома способами: звинувачуваного або просто забивали камінням, або піднімали на висоту і один з поводирів зіштовхував приреченого, а інший скочував на нього великий камінь.

Про цей вид покарання згадується ще в Біблії. Проте Ісус Христос мудро висловлює своє ставлення до злочинниці і до смертної кари загалом: «Коли книжники і фарисеї привели до Нього цю жінку і спитали Його, чи варто ï побити камінням, як велить закон Мойсея, Він відповів: нехай кине першим камінь той, хто відчуває себе безгрішним» $[2,183]$.

До категорії страт, де виконавцями вироку ставали самі глядачі, відноситься ганебний стовп . Цей вид покарання був дуже поширеним способом покарання у всі часи й за будь-якого соціального устрою. Засудженого прив'язували на публічному місці біля ганебного стовпа на певний час — від декількох годин до декількох днів - на загальне посміховисько. Погода, що могла погіршитись у цей час, ускладнювала становище жертви і збільшувала страждання, що, ймовірно, трактувалось як «кара божа». Таке покарання порівняно $з$ іншими видається значно м'якшим, та, $з$ іншого боку, прикуті до стовпа були зовсім беззахисними перед «судом народу»: будь-хто міг зганьбити їх словом чи вчинком, плюнути на них чи кинути камінь - така поведінка, причиною якої могло бути народне обурення чи особиста неприязнь, інколи призводила до каліцтва чи навіть смерті засудженого.

Диба. Суть цієї страти полягала в тому, що засудженому одним кінцем мотузки зв'язували за спиною руки, а другий іiі кінець прив'язували до корби, розміщеної на високому дерев'яному стовпі. Накручуючи корбу, кат піднімав жертву над землею, після чого корбу різко відпускали. Мотузка не давала засудженому впасти на землю, але вивертала його плечові суглоби, розриваючи сухожилля. Потому людина практично не володіла руками.

Ублієти - породження римської культури. Ублієти - це провалля, на дні якого вістрям догори чи вбік стирчали списи. Зазвичай з їх допомогою розправлялися з ворогами.

Загалом страта вважалася всенародним урочистим заходом. Як кидання злочинців на поживу диким звірам у язичницькому Стародавньому Римі, так і спалення єретиків католицькою інквізицією призначалось у певні дні, для ознаменування святкових державних подій.

У Росії сенаторським наказом від 7 травня 1744 року, в період двадцятилітнього правління Слизавети Петрівни, смертна кара була формально відмінена повністю (застосовувалась у завуальованому вигляді - шмагання до смерті батогами, палками, різками), а надалі запроваджувалась за іменним наказом царів (наприклад, страта Катериною II Омеляна Пугачова та його сподвижників).

В епоху Просвітництва аболіціоністський рух, спрямований проти смертної кари, поступово знаходив своїх прихильників. Спочатку відмінили лише урочистість обстановки, що панувала навколо ешафоту, і для виконання вироку стали призначати відлюдні місця і по можливості вранішні години доби. Останнім часом у більшості європейських країн діють закони, якими передбачається виконання смертної кари безпосередньо у в'язниці. В царській Росії з 1881 року смертні кари виконувалися в межах тюремної огорожі або в іншому не публічному місці. Тобто страти втрачають свою ознаку публічності й за суттю перестають бути формою масового свята. Фактично смертні кари перестають бути масовими видовищами і їх не можна відносити до категорії масо- 
вих свят. Згодом рух за скасування смертної кари як такої набуває поширення: наприклад, у Колумбії страта злочинців відмінена в 1863 р., у Венесуелі - в 1864, у Румунії - в 1864, Коста-Ріці в 1880 , у Голландії - в 1870.

Публічність смертної кари в СРСР протрималась до ХX століття - за свідченням очевидців, останньою публічною стратою в Києві було повішання в 1944 році на площі Калініна (нині майдан Незалежності) чотирьох німецько-фашистських злочинців. Тобто ще зараз живі свідки таких публічних заходів. Нині людство поступово змінюе своє ставлення до смертних вироків загалом та до їх публічної та театрально-видовищної складової зокрема.

Досліджуючи питання театралізації публічної смертної кари в епоху Середньовіччя ми лише поверхово торкнулися особливостей їх національних характеристик. Неохопленим залишився й аспект наступництва і впливу таких каральних заходів на сучасне сценічне мистецтво та суспільну культурно-дозвільну діяльність. Зазначені перспективи подальших досліджень підтверджують значимість даного феномену як особливого різновиду театралізованих дійств і його приналежність до фонду загальнолюдських цінностей.

1 Інквізиція (від лат. Inqusitio - розслідування, розшук) - особливий слідчий та судовий орган, який існував у XIII-XIX ст. і головним завданням якого була боротьба з єресями. Інквізаційний суд був таємним, без участі сторін. Методами інквізиції були шпигунство, катування, залякування.

2 Упланд - довгий, просторий урочистий верхній чоловічий одяг знаті й багатих містян, з рукавами та обов'язковою опояскою, часто з шалеподібним коміром, іноді хутряним, з рукавами вузькими вгорі й дуже розширеними донизу.

${ }^{3}$ Санбеніто - буквально «святий мішок» - особливий одяг жовтого кольору, в якому спалювали засуджених інквізицією.

${ }^{4}$ Соборне уложення (також Соборне укладення, Соборне уложення царя Олексія Михайловича) - універсальний кодекс кримінального та цивільного права Московської держави, прийнятий Земським собором у 1649 році. Діяв майже 200 років, до 1832 року. Регулював соціально-правові відносини у всіх сферах суспільного життя та визначав міру покарання за порушення цих норм. Прийняте в 1649 р. в часи правління царя Олексія Михайловича.

5 Карнаушаніє — дослівно «обрізання вух». Застосовувалося таке покарання до шахраїв або до підручних злодіїв. За значне злодійство відрізали ліве вухо. Якщо таких злочинів було три, то жертву страчували.
6 На прохання сім’ї справа Жанни д’Арк розглядалось в 1450, і вона визнана невинною. В 1894 канонізована.

${ }^{7}$ Один 3 різновидів четвертування - покарання шляхом розривання тіла навпіл — відомий ще в язичницькій Русі. Полягало воно в тому, що жертву прив'язували за ноги до двох нахилених молодих дерев, а потім відпускали їх. За візантійськими джерелами, саме так древляни стратили князя Ігоря в 945 році за те, що хотів утретє зібрати з них подать.

\section{Джерела та література}

1. Смертная казнь [Електронний ресурс] / Энциклопедический Словарь Ф. А. Брокгауза и И. А. Ефрона. - Режим доступа: http://www.vehi.net/brokgauz/. Название с экрана.

2. Кистяковский А.Ф. Исследование смертной казни [Текст] / Александр Фёдорович Кистяковский. Тула : Автограф, 2000. - 272 с.

3. Інквізиція [Текст] / Словник іншомовних слів / За ред. О.С. Мельничука. - К. : ГР УРЕ АН УРСР, 1974. - C. 284.

4. Шишов О.Ф. Смертная казнь в истории России [Текст] / Олег Фёдорович Шишов // Келина С. Г. Смертная казнь: за и против (сборник) ; отв. ред. О.Ф. Шишов, С. Г. Келина. - М. : Юрид. лит., 1989. -528 с.

5. Хёйзинга Й. Осень Средневековья: Исследования форм жизненного уклада и форм мышления в XIV и XV веках во Франции и Нидерландах / Сост. и пер. с нидерландского Д. В. Сильвестрова. - 4-е изд. - М. : Айрис-пресс, 2004. - 537 с.

6. Беккаріа Ц. О преступлениях и наказаниях ; [перев. И. Соболева]. — Радомъ : типо-литография И. С. Тржебинского, 1878. - 134 с.

7. Вольтер. Философские повести [Текст] / Вольтер ; пер. с фр. - М. : Художественная литература, 1954. - $354 \mathrm{c}$.

8. Біблія, або Книги святого письма Старого і Нового Заповіту: Євангеліє від св. Івана. - Будь-яке видання.

9. Ле Гофф Ж. Цивилизация средневекового Запада [Текст] / Жак Ле Гофф ; пер. с фр. ; [общ. ред. Ю. Л. Безсмертного ; послесл. А. Я. Гуревича]. - М. : Прогресс ; Прогресс-Академия, 1992. - 376 с.

10. Жанна Д’Арк [Текст] // Иллюстрированный энциклопедический словарь Ф. Брокгауза и И. Ефрона. - М. : Эксмо, 2007. - С. 280.

11. Гуревич А. Я. Средневековый мир: Культура безмолствующего большинства [Текст] / Арон Якович Гуревич. - М. : Искусство, 1990. - 396 с.

12. Біблія, або Книги святого письма Старого i Нового Заповіту. П'ятикнижжя Мойсеєве: Третя книга Мойсеєва - Левит. - Будь-яке видання.

13. Біблія, або Книги святого письма Старого i Нового Заповіту. П'ятикнижжя Мойсеєве: Друга книга Мойсеєва - Вихід. - Будь-яке видання.

14. Декабристы [Текст] // Иллюстрированный энциклопедический словарь Ф. Брокгауза и И. Ефрона. - М. : Эксмо, 2007. - С. 263. 